$1-1-1955$

\title{
Livestock Marketing Practices of West Virginia Farmers
}

W. S. Hutson

Follow this and additional works at: https://researchrepository.wvu.edu/ wv_agricultural_and_forestry_experiment_station_bulletins

\section{Digital Commons Citation}

Hutson, W. S., "Livestock Marketing Practices of West Virginia Farmers" (1955). West Virginia Agricultural and Forestry Experiment Station Bulletins. 384.

https://researchrepository.wvu.edu/wv_agricultural_and_forestry_experiment_station_bulletins/374 @ WVU. It has been accepted for inclusion in West Virginia Agricultural and Forestry Experiment Station Bulletins by an authorized administrator of The Research Repository @ WVU. For more information, please contact ian.harmon@mail.wvu.edu. 
Digitized by the Internet Archive in 2010 with funding from

Lyrasis Members and Sloan Foundation 


\section{BULLETIN 384}

December 1955

\section{Livestock Marketing Practices}

of West Virginia Farmers 


\section{THE AUTHOR}

W. S. HUTSON is Assistant Agricultural Economist at the West Virginia University Agricultural Expermient Station and (Agent) Agricultural Economist in the Market Organization and Costs Branch, Marketing Research Division, Agricultural Marketing Service, United States Department of Agriculture.

WEST VIRGINIA UNIVERSITY

Agricultural EXPERIMENT Station

College of Agriculture, Forestry, and Home Economics

H. R. VARNey, DiREctor

MORGANTOWN 


\section{SUMMARY}

The long-time trend of numbers of cattle and calves in West Virginia has been upward and number of hogs and sheep downward.

Total meat animal production in West Virginia from 1924 to 1952, inclusive, averaged 54 per cent beef and veal, 33 per cent pork, and 13 per cent lamb and mutton.

In 1950, approximately two-thirds of the cattle and calves, slightly more than one-half of the hogs and pigs, and two-thirds of the sheep and lambs marketed from West Virginia farms were sold through auctions.

Accessibility of the auctions seems to be one of their strong points. Eighty per cent of the cattle and calves, 86 per cent of the hogs, and 92 per cent of the sheep and lambs sold through the auction were hauled less than 30 miles.

Convenience was the most common reason for choosing a market, with better prices second.

West Virginia farmers reporting sales of livestock by species in 1950 indicated that of the farmers selling a designated species, an average of eight head of cattle was sold per farm, two head of veal per farm, ten head of hogs, and 26 head of sheep.

About one-sixth of the cattle and calves, one-sixth of the hogs and pigs, and 3 per cent of the sheep and lambs were sold to local dealers or truck buyers.

Fifteen per cent of the sheep and lambs and 1 per cent of the hogs and pigs and 1 per cent of the cattle and calves were sold through cooperative associations.

Twenty-nine per cent of the hogs and pigs, 14 per cent of the cattle and calves, and 13 per cent of the sheep and lambs were sold to other farmers. Two per cent or less of each species were sold through terminal markets, and less than 2 per cent of each species were sold direct to packing plants.

Practically all livestock in West Virginia were moved to market by truck. The buyer moved 23 per cent of the cattle, 31 per cent of the hogs, and 31 per cent of the sheep from the farms. The farmer moved 39 per cent of the cattle, 46 per cent of the hogs, and 40 per cent of the sheep to market in his own truck. Thirty-eight per cent of the cattle, 23 per cent of the hogs, and 46 per cent of the sheep were moved from farms in hired trucks. 
Cattle marketed were reported to be 57 per cent beef breeds, 16 per cent mixed, and 27 per cent dairy breeds. Thirty-two per cent of the cattle and calves were sold for slaughter, plus an additional 34 per cent sold as veal calves, 23 per cent were sold as stockers and feeders, and 11 per cent for dairy and breeding.

Only 1 per cent of the hogs were sold for breeding purposes, 54 per cent were sold for feeding, and 45 per cent for slaughter.

Seventy per cent of the sheep were sold for slaughter, 27 per cent for breeding, and 3 per cent for feeding.

Eighty-seven per cent of West Virginia farmers reporting sales of slaughter cattle and calves sold only grass-fat cattle and only 13 per cent fed some grain.

Seven per cent of the farmers selling sheep and lambs reported some grain feeding of slaughter lambs. The other 93 per cent grazed only. 


\section{Livestock Marketing Practices of}

\section{West Virginia Farmers*}

\section{INTRODUCTION}

W. S. HUTSON

Livestock is a major source of income for West Virginia agriculture (Figure 1). The agricultural resources of the State indicate that livestock production will remain a major farm enterprise. Even though dairy cattle will probably continue to increase in relative importance the marketing of meat animals from a dairy herd will constitute a significant part of the enterprise.

\section{Purpose}

This study was conducted in order to learn the livestock marketing practices of West Virginia farmers, giving emphasis to what type of market agencies farmers use in their selling and buying operations.

\section{Source of Data}

Unless otherwise stated, information presented in this report was obtained from personal interviews with a sample of 416 livestock producers in West Virginia who had sold or bought livestock during 1950.1

* This study is a part of a regional plan of livestock marketing research in which a number of Southern states and the Agricultural Marketing Service, U.S. Department of Agriculture, are cooperating. Each state is conducting its research program; however, there is joint planning and coordination of research through a Regional Technical Committee representing each of the participating states and agencies. Participating states include Alabama, Arkansas, Louisiana, Mississippi, Georgia, South Carolina, North Carolina, Tennessee, Virginla, and West Virginia.

1Earl E. Houseman, Agricultural Marketing Service, served as consultant and supervised the drawing of the sampie.

The universe sampled was comprised of all farms in the open country portions of West Virginia from which livestock or livestock products, except poultry and dairy products, were sold in 1950 .

All counties in the State were grouped into 21 strata, eight of which were composed of one county each and the remaining 13 were composed of two or more contiguous counties each. Upshur and Braxton counties were a single exception to non-contiguous counties being used as a stratum. These strata were made as nearly equal in size in terms of value of livestock and livestock products sold ( 1945 Census) as practicable.

One county was selected at random from each stratum with probabilities proportional to the value of livestock and livestock products sold. Of course, those eight counties which comprised a separate stratum each were included in the sample with certainty.

The selected counties were sub-sampled by selecting area segments as delineated in the Master Sample of Agriculture by applying the interval systematically from a random start to a listing of all sampling units in the open country portion of each sample county. 


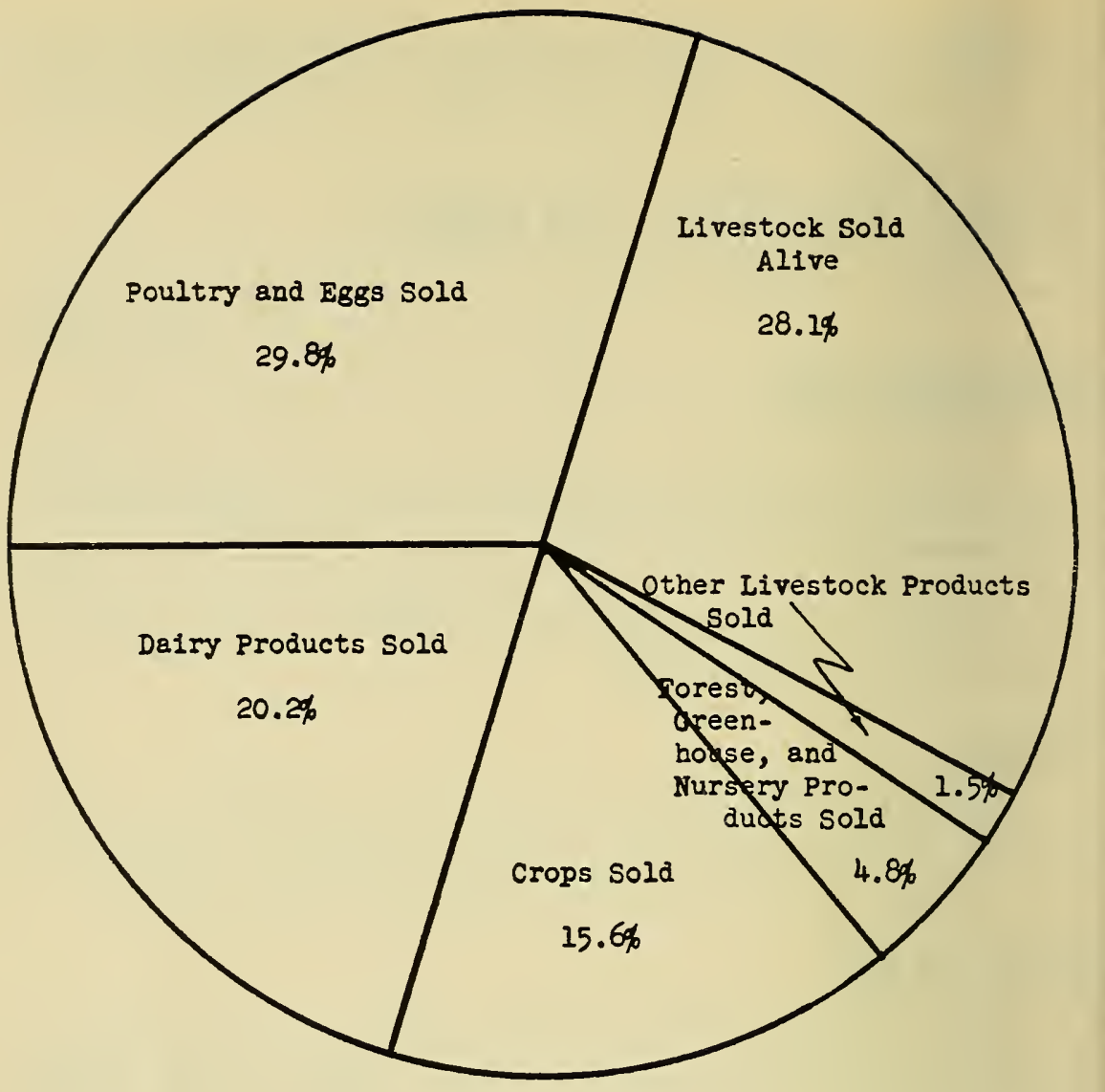

1950

$(\$ 116,614,000)$

FIGURE 1. Sources of cash receipts from farm marketings for West Virginia farmers in 1950. (Source: The Farm Income Situation, BAE, USDA, June-July 1952.)

\section{TRENDS IN WEST VIRGINIA LIVESTOCK INDUSTRY} Livestock Numbers on Farms

Cattle. Cattle and calf numbers in West Virginia first reached the half-million mark in 1883 . They have remained at or above that number since, except from 1895 to 1898 inclusive and from 1927 to 1929 inclusive. 
Milk cows ${ }^{2}$ accounted for an average of 32 per cent of the total cattle and calves on West Virginia farms in 1883 and the 11 years following. This increased to an average of 39 per cent for the two decades beginning 1895. From 1915 to 1925 the number of milk cows dropped again to about one-third of the total. For the three decades beginning 1925 the relative number of milk cows increased to an average of 41 per cent of all cattle and calves. For these three decades the percentage has varied within plus or minus 3 per cent of the average except for 1953 and 1954 when 37 per cent of the number of cattle and calves were milk cows.

The long-time trend has been upward for all cattle and calves and also for milk cows when considered separately (Figure 2). Numbers of milk cows have shown less year-to-year variation than numbers of all cattle (Figure 2).

Hocs. On January 1, 1954, there were 149,000 hogs on West Virginia farms. This was the lowest number of hogs since reports were

2Cows and heifers 2 years old and over kept for milk.

Thousand

Head

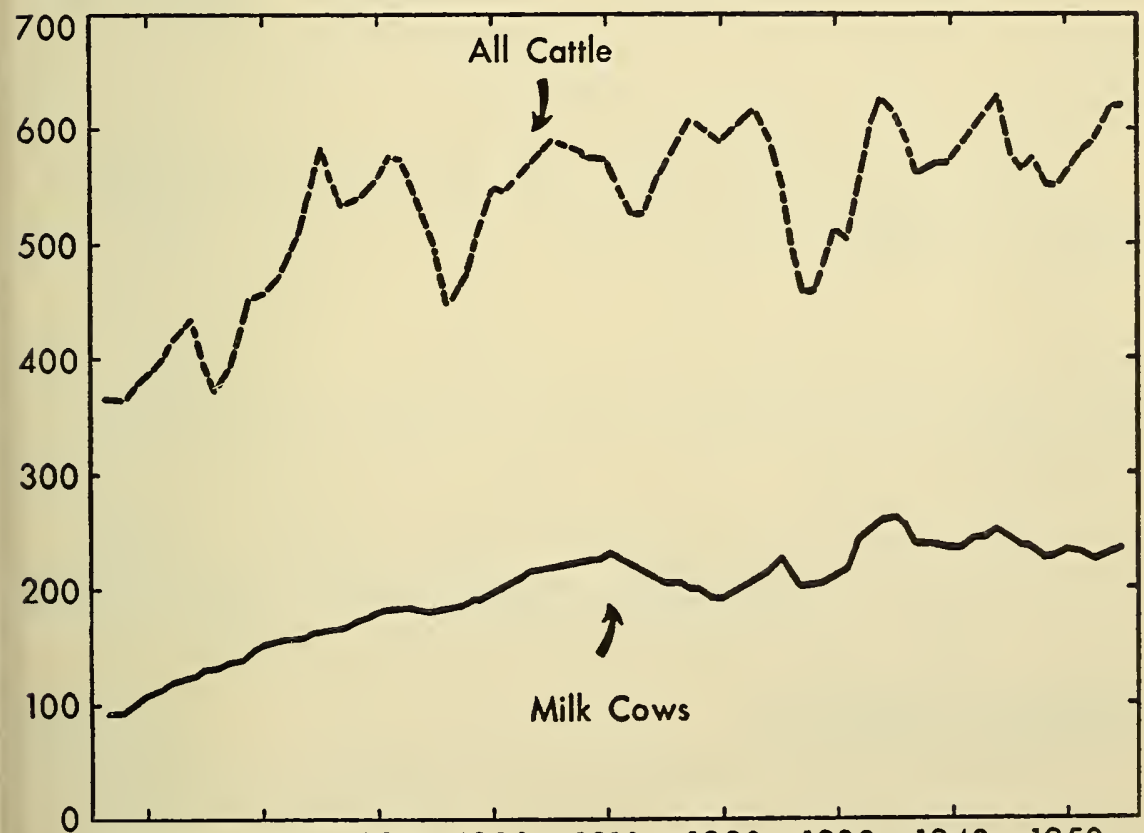

$\begin{array}{lllllllll}1870 & 1880 & 1890 & 1900 & 1910 & 1920 & 1930 & 1940 & 1950\end{array}$

FIGURE 2. Number of all cattle and calves and number of milk cows* on West Virginia farms, January 1, 1867-1954. (*Denotes cows and helfers two years old and over kept for milk.) 


\section{Thousands}

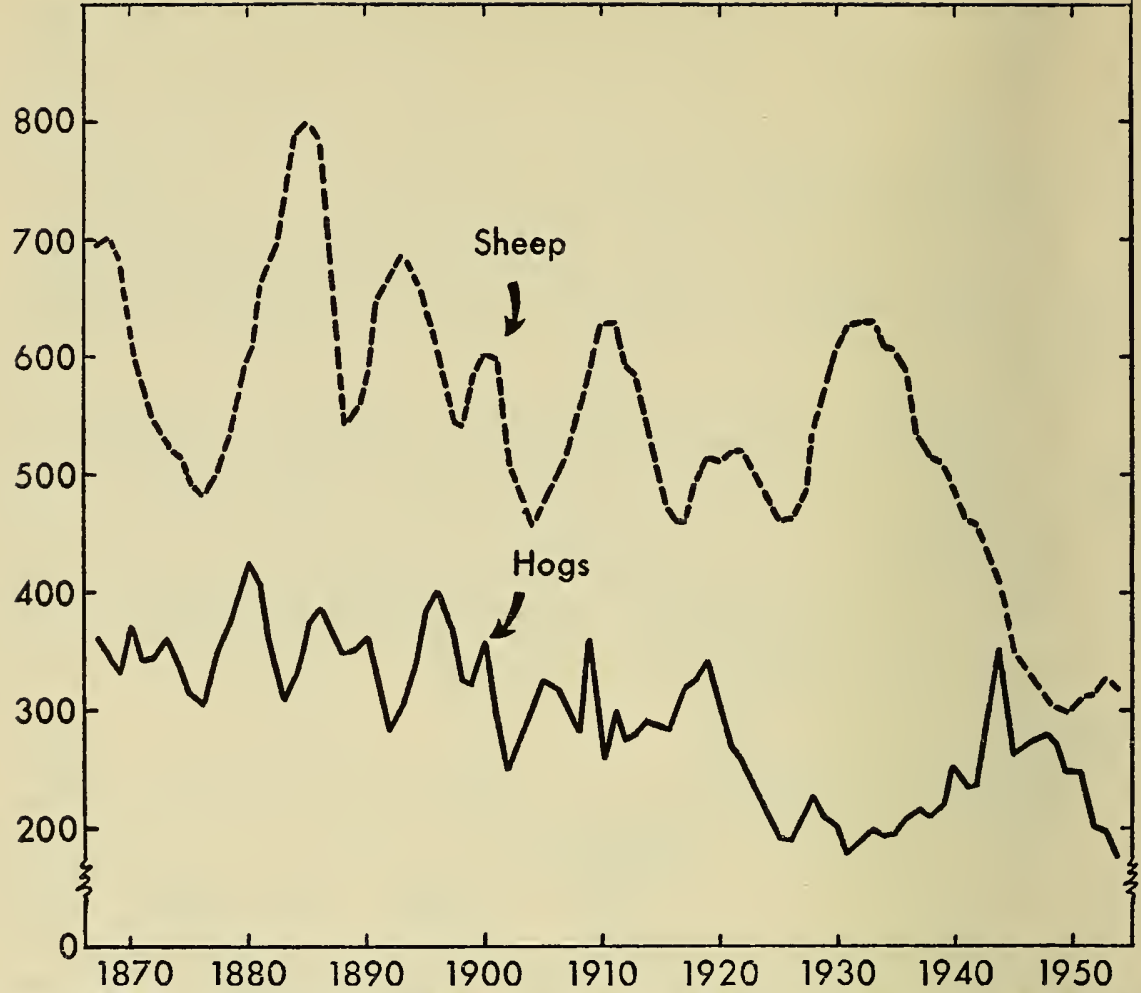

FIGURE 3. Number of hogs and number of sheep on West Virginia farms, January 1, 1867-1954.

first issued by the U.S. Department of Agriculture in 1867. The longtime trend of hog population in West Virginia has been downward (Figure 3).

SHEEP. Since 1867 , when information was first available, sheep on West Virginia farms have ranged from a high of 800,000 on January 1 , 1885 , to a low of 296,000 in 1950 . The long-time trend of numbers of sheep on West Virginia farms has been downward (Figure 3).

\section{Livestock Production}

Total meat animal production in West Virginia from 1924 to 1952, inclusive, averaged 54 per cent beef and veal, 33 per cent pork, and 13 per cent lamb and mutton. ${ }^{3}$ By comparison, the national meat animal

3Computed from annual figures available beginning with 1924 in the U.S.D.A. publication Meat Animals, Farm Production and Income. 
production is considered to be about 48 per cent beef and veal, 48 per cent pork, and 4 per cent lamb and mutton. (See Table 1 for average yearly production.)

Table 1. Number of Pounds of Livestock Produced in Specified Periods, West Virginia

\begin{tabular}{|c|c|c|c|}
\hline \multirow[b]{2}{*}{ SPECIES } & \multicolumn{3}{|c|}{ POUNDS OF MEAT ANIMALS PRODUCED } \\
\hline & $\begin{array}{c}\text { 1924-1952 } \\
\text { Average }\end{array}$ & $\begin{array}{c}1945-1949 \\
\text { AVERAGE }\end{array}$ & $\begin{array}{c}1950-1952 \\
\text { AVERAGE }\end{array}$ \\
\hline 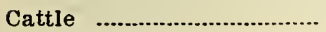 & $112,230,000$ & $114,976,000$ & $118,376,000$ \\
\hline Hogs & $67,218,000$ & $75,987,000$ & $64,917,000$ \\
\hline 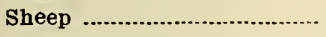 & $26,134,000$ & $18,627,000$ & $18,006,000$ \\
\hline Total & $205,582,000$ & $209,590,000$ & $201,299,000$ \\
\hline
\end{tabular}

\section{Livestock Marketings}

From 1924 through 1952 West Virginia farmers marketed an average of $150,703,000$ pounds of meat animals per year. ${ }^{*}$ Of this, 71 per cent was beef and veal, 12 per cent pork, and 17 per cent lamb and mutton.

Pork marketed accounts for only 12 per cent of the total meat marketed, whereas pork produced accounts for 33 per cent of the total meat produced. The difference in this percentage is explained by the Iarge number of hogs slaughtered on the farm. Hogs slaughtered on the farm exceeded the number marketed in every year from 1924 through 1952, and on the average more than twice as many hogs were slaughtered on the farm as were marketed.

In 1924 the number of calves marketed was approximately one-half of the number of more mature cattle marketed. This relationship increased to nine-tenths in 1927 and decreased to about one-half again in 1933. After 1933 the proportion of calves increased again until in 1944 there were more calves marketed than cattle other than calves. Calves marketed continued to increase relatively, and in 1952 they constituted 175 per cent of the more mature cattle marketed. (See Table 2 for number of livestock marketed.)

\section{Cash Receipts from Livestock Marketings}

For the five-year period 1945-1949, cash receipts of West Virginia farms from all meat animals averaged $\$ 32,614,000$ per year. Of this, $\$ 21,931,000$ was from cattle and calves, $\$ 7,143,000$ from hogs, and $\$ 3,540,000$ from sheep and lambs. ${ }^{5}$ (See Figure 4 for distribution of meat animal income in 1949.) 
Table 2. Livestock Marketed in Specified Periods, West Virginia

\begin{tabular}{|c|c|c|c|}
\hline \multirow[b]{2}{*}{ SPECIES } & \multicolumn{3}{|c|}{ NUMBER OF ANIMALS MARKETED } \\
\hline & $\begin{array}{c}1924-1952 \\
\text { AVERAGE }\end{array}$ & $\begin{array}{c}1945-1949 \\
\text { AVERAGE }\end{array}$ & $\begin{array}{c}1950-1952 \\
\text { AvERAGE }\end{array}$ \\
\hline 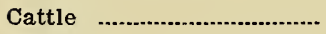 & 194,000 & 231,000 & 216,000 \\
\hline Hogs & 84,000 & 105,000 & 105,000 \\
\hline Sheep ……................................ & 310,000 & 227,000 & 191,000 \\
\hline
\end{tabular}

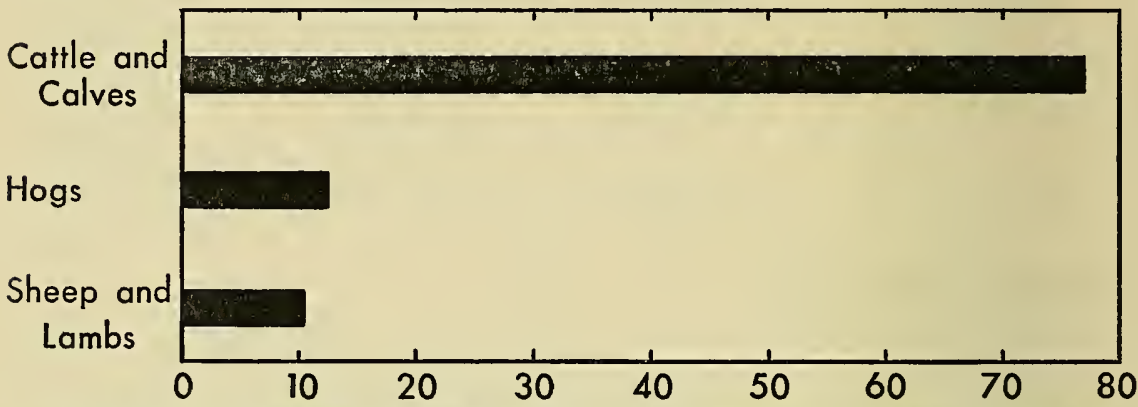

FIGURE 4. Percentage of meat animal income derived from sale of cattle and calves, hogs, and sheep and lambs, West Virginia, 1949. (Source: U.S. Census of Agriculture.)

Since cash receipts are affected by the general price level and the relative demand and supply situation, they are of little value in determining trends in quality, type, grade, or weights of livestock.

\section{MARKETING AGENCIES USED BY PRODUCERS Outlets Used by Farmers When Selling}

Cattre and Galves. Data collected from a sample of West Virginia livestock producers in 1950 indicated that approximately two-thirds of all classes of cattle and calves were sold through auctions. (See Figure 5.) Table 3 indicates a range from roughly three-fourth of the slaughter cattle and veal calves to one-half of the stockers and feeders and onethird of the dairy and breeding animals. The percentage of farmers reporting sales of the various classes of cattle and calves through auctions was approximately the same as the percentage of cattle and calves reported sold through this agency. This indicates that size of the producer had little influence on the choice of this market channel.

Sixteen per cent of all classes of cattle and calves were sold to local dealers or truck buyers, ranging from 10 per cent of veal calves to 21 per cent of the more mature slaughter cattle. More than one-half of the dairy and breeding animals and one-fourth of the stockers and feeders were sold directly to other farmers. (See Table 3 for information by classes.) 
Table 3. Use of Specified Market Outlets by West Virginia Farmers Selling Cattle and Calves in 1950, by Market Classes

\begin{tabular}{|c|c|c|c|c|c|c|c|c|}
\hline \multirow[b]{2}{*}{$\begin{array}{l}\text { MARKETING } \\
\text { AGENCIES }\end{array}$} & \multicolumn{2}{|c|}{$\begin{array}{c}\text { SLaughter Cattle } \\
\text { (EXCEPT VeaL } \\
\text { CALVES) }\end{array}$} & \multicolumn{2}{|c|}{ Veal Calves } & \multicolumn{2}{|c|}{$\begin{array}{c}\text { STOCKERS } \\
\text { AND } \\
\text { FEEDERS }\end{array}$} & \multicolumn{2}{|c|}{$\begin{array}{c}\text { DAIRY } \\
\text { AND } \\
\text { BREEDING }\end{array}$} \\
\hline & $\begin{array}{l}\text { FARMERS } \\
\text { SELIING }\end{array}$ & $\begin{array}{l}\text { Cattle } \\
\text { aNd } \\
\text { CALVES } \\
\text { Sold }\end{array}$ & $\begin{array}{l}\text { FARMERS } \\
\text { SELLING }\end{array}$ & $\begin{array}{l}\text { Calves } \\
\text { Sold }\end{array}$ & $\begin{array}{l}\text { FARMER } \\
\text { SELIXING }\end{array}$ & $\begin{array}{l}\text { CATTLE } \\
\text { AND } \\
\text { CaLVES } \\
\text { Sold }\end{array}$ & $\begin{array}{l}\text { FARMERS } \\
\text { SELLING }\end{array}$ & $\begin{array}{l}\text { CATTLE } \\
\text { AND } \\
\text { CALVES } \\
\text { Sold }\end{array}$ \\
\hline & Per Cent & Per Cent & Per Cent & Per Cent & Per Cent & Per Cent & Per Cent & Per Cent \\
\hline $\begin{array}{l}\text { Terminal } \\
\text { Markets }\end{array}$ & .7 & 7.2 & - & - & - & - & & - \\
\hline Auctions ........... & 75.0 & 70.6 & 67.1 & 77.8 & 48.6 & 53.8 & 34.1 & 31.1 \\
\hline Truck Buyer & 18.4 & 20.8 & 21.9 & 10.0 & 20.8 & 18.8 & 20.0 & 13.5 \\
\hline Packing Plant & 1.5 & .5 & 1.4 & 4.2 & - & - & - & - \\
\hline Co-op Assn. ... & - & 一 & 3.2 & 2.6 & 2.8 & 1.9 & - & - \\
\hline Other Farmers & 4.4 & .9 & 6.4 & 5.4 & 27.8 & 25.5 & 45.9 & 55.4 \\
\hline Total & 100.0 & 100.0 & 100.0 & 100.0 & 100.0 & 100.0 & 100.0 & 100.0 \\
\hline
\end{tabular}

Table 4. Use of Specified Market Outlets by West Virginia Farmers Selling Hogs in 1950, by Market Classes

\begin{tabular}{|c|c|c|c|c|c|c|}
\hline \multirow{2}{*}{$\begin{array}{l}\text { MARKETING } \\
\text { AGENCIES }\end{array}$} & \multicolumn{2}{|c|}{ SLAUGHTER } & \multicolumn{2}{|c|}{ FEEDER } & \multicolumn{2}{|c|}{ BREEDING } \\
\hline & $\begin{array}{l}\text { FARMERS } \\
\text { SELLING }\end{array}$ & $\begin{array}{l}\text { HOGS } \\
\text { SOLD }\end{array}$ & $\begin{array}{l}\text { FARMERS } \\
\text { SELLING }\end{array}$ & $\begin{array}{l}\text { HOGS } \\
\text { SOLD }\end{array}$ & $\begin{array}{l}\text { FARMIERS } \\
\text { SELLING }\end{array}$ & $\begin{array}{l}\text { HOGS } \\
\text { SOLD }\end{array}$ \\
\hline & Per cent & Per cent & Per cent & Percent & Per cent & Per cent \\
\hline $\begin{array}{l}\text { Terminal Market } \\
\text { Auctions }\end{array}$ & 1.6 & 3.1 & - & 5 & - & - \\
\hline Auctions ............ & 61.3 & 70.5 & 27.0 & 35.6 & 20.0 & 12.5 \\
\hline $\begin{array}{l}\text { Local Dealer or } \\
\text { Truck Buyer }\end{array}$ & 16.1 & 21.8 & 12.7 & 12.3 & 40.0 & \\
\hline Packing Plant ... & 1.6 & .4 & 1 & - & 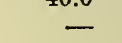 & - \\
\hline Co-op Assn. ........ & - & - & 1.6 & 1.8 & - & - \\
\hline Other Farmers .... & 19.4 & 4.2 & 58.7 & 50.3 & 40.0 & 62.5 \\
\hline Total & 100.0 & 100.0 & 100.0 & 100.0 & 100.0 & 100.0 \\
\hline
\end{tabular}

SHEEP AND LAmbs. As with cattle and hogs, the auction is the most popular market for sheep and lambs, acting as agent in the sales of two-thirds of these animals.

The cooperative association is more popular in the sale of sheep and lambs than with other species, handling 15 per cent of these animals. (See Figure 5.)

As in other species, most of the breeding animals are sold directly to other farmers. Thirteen per cent of the sheep and lambs were handled in this manner. (See Table 5 for information by classes.)

\section{Sources of Livestock Purchases}

Cattle and Calves. Fifty-three per cent of the cattle and calves bought by West Virginia farmers were purchased at auctions, and 37 
Table 5. Use of Specified Market Outlets by West Virginia Farmers Selling Sheep in 1950, by Market Classes

\begin{tabular}{|c|c|c|c|c|c|c|}
\hline \multirow{2}{*}{$\begin{array}{c}\text { MARKETING } \\
\text { AGENCIES }\end{array}$} & \multicolumn{2}{|c|}{ SLAUGHTER } & \multicolumn{2}{|c|}{ Feeder } & \multicolumn{2}{|c|}{ BREEDING } \\
\hline & $\begin{array}{l}\text { FARMERS } \\
\text { SELLING }\end{array}$ & $\begin{array}{c}\text { SHEEP } \\
\text { SOLD }\end{array}$ & $\begin{array}{c}\text { FARMers } \\
\text { SELLING }\end{array}$ & $\begin{array}{l}\text { SHEEP } \\
\text { SoLD }\end{array}$ & $\begin{array}{l}\text { Farmers } \\
\text { SELLING }\end{array}$ & $\begin{array}{c}\text { SHEEP } \\
\text { SoLD }\end{array}$ \\
\hline & Per cent & Per cent & Per cent & Per cent & Per cent & Per cent \\
\hline Terminal Market & 1.6 & 3.3 & - & - & - & - \\
\hline Auctions & 68.8 & 74.3 & 66.6 & 75.5 & 35.7 & 46.4 \\
\hline Local Dealer or & & & & & & \\
\hline Truck Buyer .... & 6.2 & 2.7 & - & - & 7.1 & 4.9 \\
\hline Packing Plant .... & - & - & - & - & 一 & - \\
\hline Co-op Assn. ......... & 23.4 & 19.7 & 33.3 & 24.5 & 7.2 & .4 \\
\hline Other Farmers .... & - & - & - & - & 50.0 & 48.3 \\
\hline Total & 100.0 & 100.0 & 100.0 & 100.0 & 100.0 & 100.0 \\
\hline
\end{tabular}

per cent directly from other farmers. (See Figure 6, and for information by classes see Table 6. .)

Hogs. One-half of the hogs and pigs were reported bought through auctions, and another 46 per cent directly from other farmers. (See Figure 6.) More than three-fourths of the farmers reporting purchases of hogs reported buying from other farmers. (See Table 7.) These facts indicate that purchases from other farmers are more popular among those producers buying in small numbers.

Table 6. Use of Specified Market Inlets by West Virginia Farmers Buying Cattle and Calves in 1950, by Market Classes

\begin{tabular}{|c|c|c|c|c|c|c|}
\hline \multirow{2}{*}{$\begin{array}{l}\text { MARKETING } \\
\text { AGENCIES }\end{array}$} & \multicolumn{2}{|c|}{$\begin{array}{c}\text { SLaughter Cattle } \\
\text { AND CALVES }\end{array}$} & \multicolumn{2}{|c|}{$\begin{array}{c}\text { STOCKERS } \\
\text { AND FEEDERS }\end{array}$} & \multicolumn{2}{|c|}{$\begin{array}{l}\text { DAIRY AND } \\
\text { BREEDING }\end{array}$} \\
\hline & $\begin{array}{l}\text { FARMERS } \\
\text { BUYING }\end{array}$ & $\begin{array}{l}\text { Cattle } \\
\text { Bought }\end{array}$ & $\begin{array}{l}\text { FARMERS } \\
\text { BUYING }\end{array}$ & $\begin{array}{l}\text { CATTLE } \\
\text { BOUGHT }\end{array}$ & $\begin{array}{l}\text { FARMERS } \\
\text { BUYING }\end{array}$ & $\begin{array}{l}\text { CAtthe } \\
\text { Bought }\end{array}$ \\
\hline & Per cent & Per cent & Per cent & Per cent & Per cent & Per cent \\
\hline Terminal Market & - & - & 1.6 & .5 & - & - \\
\hline Auctions .................. & 57.1 & 93.5 & 36.5 & 54.7 & 20.8 & 32.4 \\
\hline Local Dealer or & & & & & & \\
\hline Truck Buyer & 14.3 & 1.3 & 6.3 & 8.5 & 7.0 & 2.8 \\
\hline Co-op Assn. & - & - & 3.2 & 4.2 & 2.8 & 1.7 \\
\hline Other Farmers .... & 28.6 & 5.2 & 52.4 & 32.1 & 69.4 & 63.1 \\
\hline Total & 100.0 & 100.0 & 100.0 & 100.0 & 100.0 & 100.0 \\
\hline
\end{tabular}

Table 7. Use of Specified Market Inlets by West Virginia Farners Buying Hogs in 1950, by Market Classes

\begin{tabular}{|c|c|c|c|c|c|c|}
\hline \multirow{2}{*}{$\begin{array}{l}\text { MARKETING } \\
\text { AGENCIES }\end{array}$} & \multicolumn{2}{|c|}{ SLAUGHTER } & \multicolumn{2}{|c|}{ FEEDER } & \multicolumn{2}{|c|}{ BREEDING } \\
\hline & $\begin{array}{l}\text { FARMERS } \\
\text { BUYING }\end{array}$ & $\begin{array}{l}\text { HoGS } \\
\text { BOUGHT }\end{array}$ & $\begin{array}{l}\text { FARMERS } \\
\text { BUYING }\end{array}$ & $\begin{array}{c}\text { HoGs } \\
\text { BOUGHT }\end{array}$ & $\begin{array}{l}\text { FARMERS } \\
\text { BUYING }\end{array}$ & $\begin{array}{l}\text { HoGs } \\
\text { BOUGHT }\end{array}$ \\
\hline Auctlons ................... & $\begin{array}{c}\text { Per cent } \\
20.0\end{array}$ & $\begin{array}{c}\text { Per cent } \\
21.4\end{array}$ & $\begin{array}{c}\text { Per cent } \\
9.6\end{array}$ & $\begin{array}{c}\text { Per cent } \\
54.0\end{array}$ & $\begin{array}{c}\text { Per cent } \\
11.1\end{array}$ & $\begin{array}{c}\text { Per cent } \\
7.1\end{array}$ \\
\hline $\begin{array}{l}\text { Local Dealer or } \\
\text { Truck Buyer } \\
\text { Other Farmers } \\
\text { Total }\end{array}$ & $\begin{array}{r}6.7 \\
73.3 \\
100.0\end{array}$ & $\begin{array}{r}2.4 \\
76.2 \\
100.0\end{array}$ & $\begin{array}{r}7.8 \\
82.6 \\
100.0\end{array}$ & $\begin{array}{r}3.5 \\
42.5 \\
100.0\end{array}$ & $\begin{array}{r}-\overline{88.9} \\
100.0\end{array}$ & $\begin{array}{r}-\overline{92.8} \\
100.0\end{array}$ \\
\hline
\end{tabular}




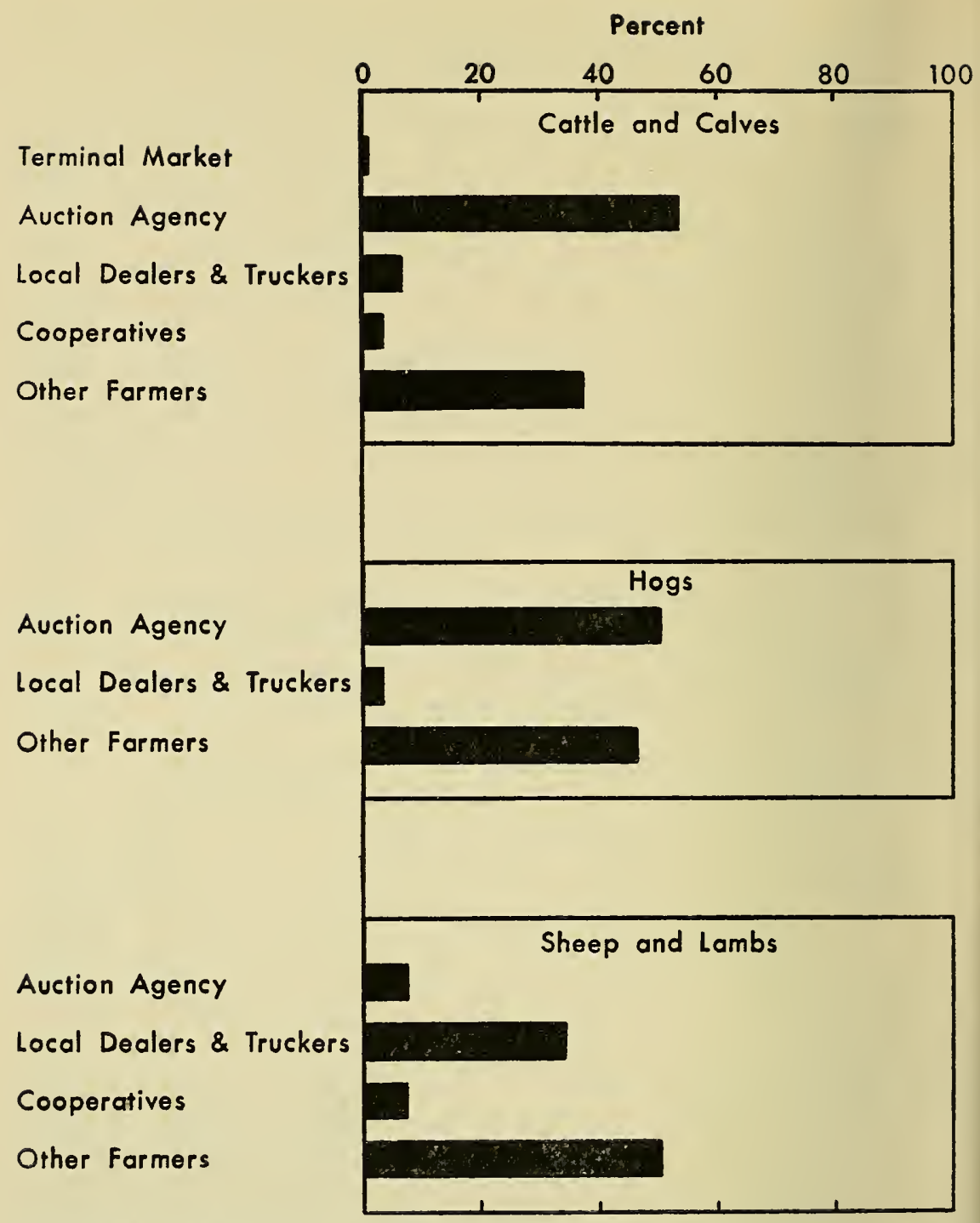

FIGURE 6. Distribution of Livestock bought through various types of markets by West Virginia farmers, 1950.

SHEEP AND LAMbs. One-half of the sheep and lambs bought by West Virginia farmers were purchased directly from other farmers, and 34 per cent were bought from local dealers or truckers. (See Figure 6, and for information by classes see Table 8.) 
Table 8. Use of Specified Market InLets by West Virginia Farmers Buying Sheep in 1950, by Market Classes

\begin{tabular}{|c|c|c|c|c|c|c|}
\hline \multirow{2}{*}{$\begin{array}{c}\text { MARKETING } \\
\text { AGENCIES }\end{array}$} & \multicolumn{2}{|c|}{ SLAUGHTER } & \multicolumn{2}{|c|}{ FEFDER } & \multicolumn{2}{|c|}{ BREEDING } \\
\hline & $\begin{array}{c}\text { FARMERS } \\
\text { BUYING }\end{array}$ & $\begin{array}{l}\text { SHEEP } \\
\text { BOUGHT }\end{array}$ & $\begin{array}{l}\text { FARMERS } \\
\text { BUYING }\end{array}$ & $\begin{array}{c}\text { SHEEP } \\
\text { BOUGHT }\end{array}$ & $\begin{array}{c}\text { Farmers } \\
\text { BuYiNG }\end{array}$ & $\begin{array}{l}\text { SHEEP } \\
\text { BOUGHT }\end{array}$ \\
\hline Auctions & Per cent & Percent & Per cent & Per cent & $\begin{array}{c}\text { Percent } \\
10.0\end{array}$ & $\begin{array}{c}\text { Per cent } \\
8.3\end{array}$ \\
\hline $\begin{array}{l}\text { Local Dealer } \\
\text { or Truck Buyer }\end{array}$ & - & 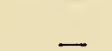 & $\longrightarrow$ & - & 15.0 & 373 \\
\hline Co-op Assn. ....... & - & - & 33.3 & 72.7 & 5.0 & 2.7 \\
\hline Other Farmers .... & 100.0 & 100.0 & 66.7 & 27.3 & 70.0 & 51.7 \\
\hline Total & 100.0 & 100.0 & 100.0 & 100.0 & 100.0 & 100.0 \\
\hline
\end{tabular}

\section{FACTORS ASSOCIATED WITH CHOICE OF MARKET Number of Animals Sold Per Farmer and Per Sale}

Choice of a marketing agency is largely dependent on the number of animals a farmer may have for sale. Convenience is given weight inversely to the number of animals to be marketed. Market outlets outside of an area would have to offer prices high enough to pay the increased costs of marketing (evident mostly in transportation and shrinkage).

Cattle and Calves. An average of two head of veals was sold per farmer selling veals in 1950 . For the same period farmers selling other cattle sold an average of eight, exclusive of veal. (For the number of sales made during the year and the usual number sold per sale see Table 9.)

Hogs. An average of ten head of hogs was sold per farmer selling hogs.

Seventy-six per cent of the farmers selling slaughter hogs reported making only one sale of about four hogs during the year. Another 10 per cent reported making two sales during the year, usually selling about seven hogs per sale. The remainder of the farmers made three or more sales but usually sold smaller numbers per transaction.

Fifty-four per cent of the farmers selling feeder hogs made only one sale during 1950, customarily selling about eight hogs at that time. Eighteen per cent made two sales during the year, ordinarily selling about seven hogs per sale. The remainder of the farmers made three or more sales during the year, and usually sold larger numbers per transaction as the number of transactions increased.

Most of the farmers reporting sales of hogs for breeding purposes made only one such sale during 1950 and that was usually one or two hogs.

Sheep and Lambs. Farmers selling sheep and lambs, sold an average of 26 sheep and lambs per farm. Sixty-five per cent of the farmers selling 
Table 9. West Virginia Farmers Making Specified Number of Sales of Cattle and the Usual Number of Cattle Sold Per Transaction in 1950, By Market Classes

\begin{tabular}{l|c|c|c}
\hline \hline Market Class & $\begin{array}{c}\text { No. Transactions } \\
\text { Per Year }\end{array}$ & $\begin{array}{c}\text { Per Cent of } \\
\text { Farmers Selling }\end{array}$ & $\begin{array}{c}\text { Usual No. of Cattle } \\
\text { Sold Per Transaction }\end{array}$ \\
\cline { 2 - 3 } & 1 & 67.7 & 3 \\
Slaughter Cattle & 2 & 20.0 & 4 \\
(Other than Veal) & $3-5$ & 6.9 & 2 \\
& $6-10$ & 3.9 & 1 \\
& Over 10 & 1.5 & 1 \\
\hline & 1 & 63.9 & 2 \\
& 2 & 18.5 & 2 \\
& $3-5$ & 14.8 & 2 \\
& $6-10$ & 0.9 & 1 \\
& Over 10 & 49.2 & 5 \\
& & 25.4 & 3 \\
& 1 & 9.5 & 2 \\
Stockers \& Feeders & 2 & 12.7 & 2 \\
\hline
\end{tabular}

slaughter sheep and lambs reported making only one sale during 1950, selling about 22 head at that time. Twenty-five per cent made two sales during the year, ordinarily selling six head per sale, and the remainder of the farmers made three or more sales during the year, selling about nine head per sale.

\section{Number of Animals Bought Per Farmer and Per Purchase}

Cattle and Calves. The West Virginia farmer who bought cattle and calves purchased an average of six cattle and calves. Those buying for dairy and breeding bought an average of three, and those buying for feeding bought an average of seven.

Seventy-eight per cent of the farmers buying feeder cattle made only one purchase during 1950, ordinarily buying about four at that time. Another 10 per cent made two transactions during the year, usually buying about three cattle per transaction. The remainder made three or more purchases during the year, customarily buying from three to five per transaction.

The percentage of farmers making specified numbers of purchases of dairy and breeding cattle during the year was approximately the same as that for feeder cattle. However, the usual number bought per transaction was one or two animals.

Hocs. West Virginia farmers buying hogs purchased an average of four hogs per farmer. Those buying for breeding bought an average 
of two, and those buying for feeding bought an average of five.

Eighty-eight per cent of the farmers buying feeder hogs made only one transaction during the year, ordinarily buying two hogs. Those making more than one transaction during the year generally bought more hogs per transaction.

SHEEP. West Virginia farmers buying sheep bought an average of 29 per farmer.

Two-thirds of the farmers buying feeder sheep made one purchase, usually of about six sheep during the year. The remaining one-third made two or more purchases and generally bought more sheep per transaction. Purchases of breeding sheep did not differ significantly from purchases of feeder sheep.

\section{Distance to Market}

Auction. Thirty-nine per cent of the farmers selling through auction markets were located within 16 miles of a market. They reported moving 40 per cent of the cattle, 48 per cent of the hogs, and 69 per cent of the sheep less than that distance. Another 44 per cent were within 16 to 30 miles of an auction and reported moving 40 per cent of the cattle, 38 per cent of the hogs, and 23 per cent of the sheep these distances.

Slaughter House. Direct sales to slaughter houses seemed to be limited to those farmers located near a plant. Eighty per cent of those reporting direct sales were located less than 16 miles from the houses to which they sold. These sales accounted for three-fourths of the cattle and all of the hogs sold directly to slaughter houses by West Virginia farmers.

Terminal Markets. Although there are no terminal markets in West Virginia, some West Virginia farmers located in the Northern Panhandle are within 35 miles of Pittsburgh or 100 miles of Cleveland. Farmers located in the Eastern Panhandle are within 75 miles of Baltimore, others located along the State's eastern border are within less than 200 miles of Richmond, and others along the Ohio River are within 150 miles of Cincinnati. With the exception of a few farmers in the Northern Panhandle, all West Virginia farmers are located nearer an auction than a terminal market.

\section{Methods of Transportation}

Practically all livestock in West Virginia were moved to market by truck. Twenty-seven per cent of the farmers selling cattle and calves moved 39 per cent of the cattle and calves to market in their own trucks, 39 per cent moved 38 per cent of the cattle to market in hired trucks, 
and 34 per cent of the farmers reported 23 per cent of the cattle were moved from their farms by the buyer. The methods of handling calves followed very closely those used in handling cattle, not differing more than 5 per cent in any instance studied.

Thirty-one per cent of the farmers selling hogs moved 46 per cent of the hogs to market in their own trucks, 26 per cent moved 23 per cent in hired trucks, and 43 per cent reported 31 per cent moved from their farms by the buyer.

Forty-two per cent of the farmers selling sheep reported moving 40 per cent of the sheep to market in their own trucks, 46 per cent moved 29 per cent in hired trucks, and 12 per cent reported 31 per cent moved from their farms by the buyers.

\section{Source and Adequacy of Market News}

About 7 per cent of West Virginia farmers interviewed reported the newspaper as their source of market information, 20 per cent the radio, and 20 per cent both the newspaper and radio. A small percentage reported direct contact with the markets, and some reported trade papers as information sources. Forty per cent of the farmers gave no attention to market news reported in the specified sources.

As to markets reported, local markets were mentioned most often as principal sources of news, with Pittsburgh, Chicago, Cincinnati, and Baltimore following closely in the order named.

About three-fourths of the farmers who reported the radio as their principal source of market news thought the reporting was sufficient for them to determine where to sell each class and grade of livestock for the highest net returns. About two-thirds felt this way about the newspapers, and slightly more than one-third about trade publications.

\section{Farmers' Reasons for Selecting the Markets Used}

When Selling. Convenience was the most common reason for choosing a market, and better prices the next most common reason, though mentioned only one-half as often as convenience. Transportation facilities, customary practice, and personal acquaintance were given importance in the order named.

When Purchasing. Convenience also was the most common reason for choosing a market. Favorable price was the second most commonly mentioned reason. There was little difference between the number of times it was mentioned and the number of times convenience was mentioned except for feeder pigs where convenience was mentioned four times as often. Number of animals from which to choose ranked third, 
followed by personal acquaintance, customary practice, and opportunity to bargain with the seller.

\section{MARKET CHARACTERISTICS OF WEST VIRGINIA LIVESTOCK}

The 1950 Census of Agriculture reports 625,306 head of livestock were sold from West Virginia farms. These included 113,694 cattle, 130,200 calves, 183,853 hogs and pigs, and 197,559 sheep and lambs.

To learn something of the characteristics of the animals marketed in West Virginia, interviewers in this study asked the farmers questions concerning kinds, types, classes, weights, and ages of livestock sold.

\section{Characteristics of Cattle Marketings}

BREed TYPE. The distribution by breed-types was reported to be 57 per cent beef, 16 per cent mixed, and 27 per cent dairy. (See Table 10. ${ }^{6}$

Table 10. Cattle of Specified Ages and Breed Type Sold by WEST VIRGINIA FARMERS IN 1950

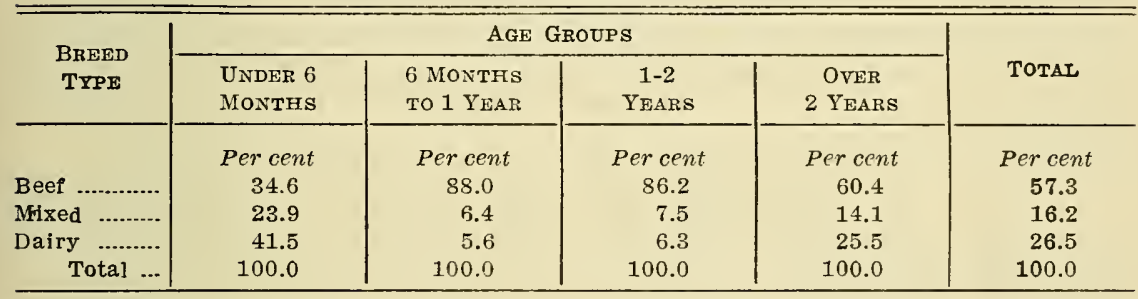

Market Class. In 1950, 34 per cent of the cattle and calves sold by West Virginia farmers were reported as veal calves. An additional 32 per cent were sold for slaughter as more mature animals, 23 per cent for stockers and feeders, and 11 per cent for dairy and breeding.

Eighty-four per cent of the farmers buying or selling livestock reported sales of cattle and calves. Of these farmers, 37 per cent reported sales of slaughter cattle other than veal, 62 per cent sales of veal calves, 18 per cent sales of stockers and feeders, and 23 per cent sales of dairy and breeding animals. A number of farmers sold more than one class of cattle.

Age at Marketing. Forty-two per cent of the cattle and calves were reported sold before reaching the age of 6 months, 12 per cent between

BProducers were asked to classify cattle and calves sold Into these three categorles: beef-type, if neither parent was considered a dairy-type animal; dairy-type, if not more than 25 per cent of blood line considered to be beef-type; mlxed-type, includes all animals not ciassifled either as dalry or beef animals. 
the age of six months to one year, 16 per cent between the ages of one to two years, and 30 per cent were sold after they were two years old. Table 10 reveals that beef-type animals were predominant in those marketed between the ages of six months to one year and one to two years, making up more than 85 per cent of those marketed in these age groups. The dairy-type animal was predominant in those sold under six months of age, and accounted for one-fourth of those animals sold when more than two years of age. The mixed-type followed the pattern of the dairy-type in showing greater percentages of sales in the under six-month and the more than two years of age groups.

Average Marketing Weights. The average weights of cattle and calves sold by West Virginia farmers were 199 pounds for those under six months; 480 pounds for those from six months to one year; 725 pounds for those from one year to two years; 961 pounds for those more than two years old. The average weight for all market classes and ages was 546 pounds.

In Table 11 the reader may see that slaughter cattle and calves were sold at heavier weights than feeder and breeding animals in all age groups except that of under six months. Feeder calves in the under six-month group averaged 225 pounds, as compared to 197 pounds for the slaughter calves and 185 pounds for those sold for breeding purposes. In the six-month to one-year age group and the one- to two-year group, the feeder and breeding animals averaged approximately the same weights, whereas in the over two-year age group, those sold for breeding purposes averaged 93 pounds heavier than those sold for feeding.

The average weight for all slaughter cattle and calves was 524 pounds, for feeder cattle and calves 536 pounds, and for breeding cattle and calves 698 pounds. The heavier average weight for breeding cattle and calves is explained by the relatively larger number of this class that was sold after reaching two years of age and the seemingly light average of all slaughter cattle and calves by the relatively larger number of animals of this class that were sold before reaching six months of age.

Methods of Finishing Cattle. Cattle and calves are not expected to produce carcasses of top grades without some grain feeding. Eighty-

Table 11. Average Weight of Cattle Sold by Farmers of West Virginia in 1950, by Age and Market Class

\begin{tabular}{|c|c|c|c|c|}
\hline \multirow{2}{*}{$\begin{array}{l}\text { MARKET } \\
\text { CLASS }\end{array}$} & \multicolumn{4}{|c|}{ AGE GROUP } \\
\hline & UNDER 6 MONTHS & $\begin{array}{c}6 \text { MoNTHS to } \\
\text { ONE YEAR } \\
\end{array}$ & 1-2 YEARS & $\begin{array}{c}\text { OVER } \\
\text { TWO YEARS }\end{array}$ \\
\hline & Pounds & Pounds & Pounds & Pounds \\
\hline Slaughter & 197 & 613 & 777 & 971 \\
\hline Feeder & 225 & 450 & 705 & 861 \\
\hline Breeding ........... & 185 & 455 & 694 & 954 \\
\hline
\end{tabular}


seven per cent of the West Virginia farmers reporting sales of slaughter cattle and calves sold only grass fat cattle and only 13 per cent fed some grain.

\section{Characteristics of Hog Marketings}

Inquiries were made as to market class, age at time of sale, and average marketing weights of hogs.

MARKET Class. One-fourth of the farmers reporting purchases or sales of livestock reported sales of hogs. Of these farmers, 55 per cent sold for slaughter, 57 per cent for feeding, and 5 per cent for breeding. Only 1 per cent of the hogs were sold for breeding purposes, whereas $\mathbf{5 4}$ per cent were sold for feeding and 45 per cent for slaughter.

Age at Time of Sale. All but 1 per cent of West Virginia's slaughter and feeder hogs were sold by the time they were one year old. More than one-half were sold before they were three months old and approximately two-thirds by the time they were five months.

Average Marketing Weights. Slaughter and feeder hogs sold under three months of age had an average weight of 36 pounds; those sold between three to five months 140 pounds; those sold between the ages of five months to one year 181 pounds, and those sold at over one year of age had an average weight of 347 pounds. The average weight of all hogs sold was 107 pounds, which emphasizes the large percentage marketed at under three months of age.

\section{Characteristics of Sheep and Lamb Marketings}

Market Class. Seventeen per cent of the farmers reporting purchases and sales of livestock reported sales of sheep and lambs. Of these, 91 per cent reported sales for slaughter, 6 per cent for feeding, and 19 per cent for breeding purposes. The proportion of farmers selling more than one class of sheep is about the same as those selling more than one class of hogs. Seventy per cent of the sheep were sold for slaughter, 27 per cent for breeding, and only 3 per cent were sold for feeding.

Age at Time of Sale. Only 2 per cent of the slaughter and feeder sheep and lambs were reported to be more than one year old when sold. Twice as many were between the ages of six months to one year, and 94 per cent were less than six months of age when sold, indicating the importance of slaughter lambs to the sheep enterprise in West Virginia agriculture.

Average Marketing Weights. Sheep and lambs sold under six months of age had an average weight of 76 pounds, those between six months and one year 88 pounds, and those over one year of age had an 
average weight of 107 pounds. All of the sheep reported sold had an average weight of 77 pounds.

Method of Finishing Sheep and Lambs. Seven per cent of the farmers selling sheep and lambs reported some grain feeding of slaughter lambs. The other 93 per cent grazed only.

\section{SEASONALITY OF LINESTOCK MARKETINGS}

Seasonal fluctuations in volume of marketings of West Virginia livestock is important to the efficient operation of the marketing agencies involved. Some agencies shut down during seasons when volume is low. This results in increased overhead costs per animal. Other agencies operate with higher variable costs per animal in order to maintain good will by supplying year-round service.

Buyers frequent those agencies whose volumes can assure them of the quantity and quality of livestock to meet their needs. Small volume during parts of the year may result in fewer buyers on the markets and less competition in establishing prices.

\section{Seasonality in Marketing Cattle and Calves}

By turning to Table 12 the reader will see that about 80 per cent of the slaughter cattle and calves moved to market from June through October, with the movement of younger animals being greater in June, July, and August, and the movement of older animals greater in September and October. Less than 6 per cent were reported sold during the first four months of the calendar year. These were almost entirely calves under 6 months of age and cows at least two years old. May accounted for 8 per cent and November and December the remaining 6 per cent of the sales of slaughter cattle and calves. More than threefourths of the sales in May were under six months of age. No age group was predominant in the November and December marketings.

Sales of 59 per cent of the stocker and feeder cattle were reported in September and October, with the one- to two-year age group showing a slight predominance. Combined sales in January, February, and March were only 2 per cent. Another 9 per cent of the sales were about equally distributed through April, May, June, and July. Ten, 12 and 8 per cent of the stocker and feeder cattle were sold in August, November, and December respectively. (See Figure 7.)

\section{Seasonality in Marketing of Hogs}

Sixty-three per cent of the slaughter and feeder hogs were reported sold from May through November, varying from 7 per cent in July to 


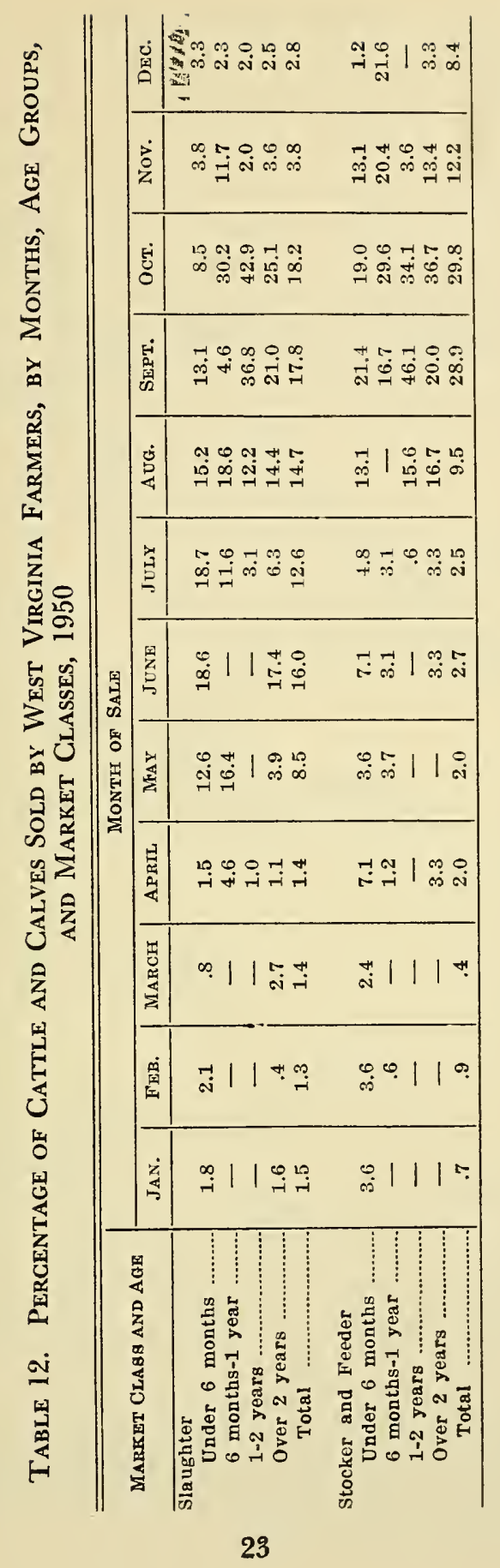




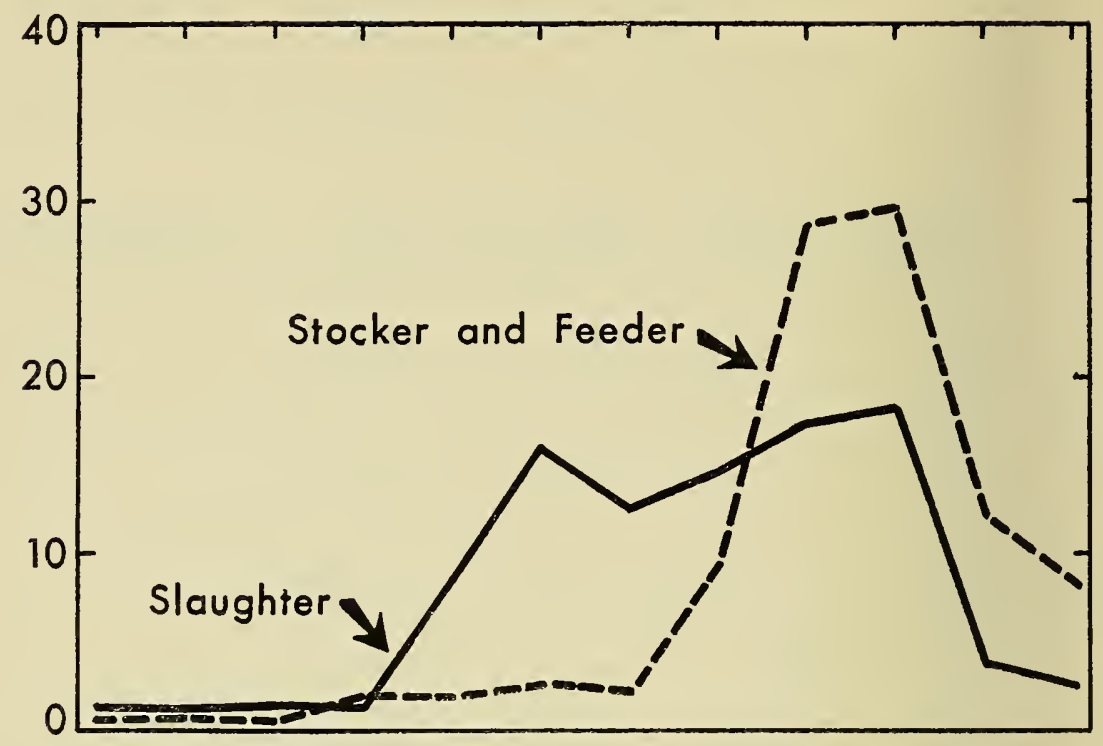

Percent

Hogs and Sheep

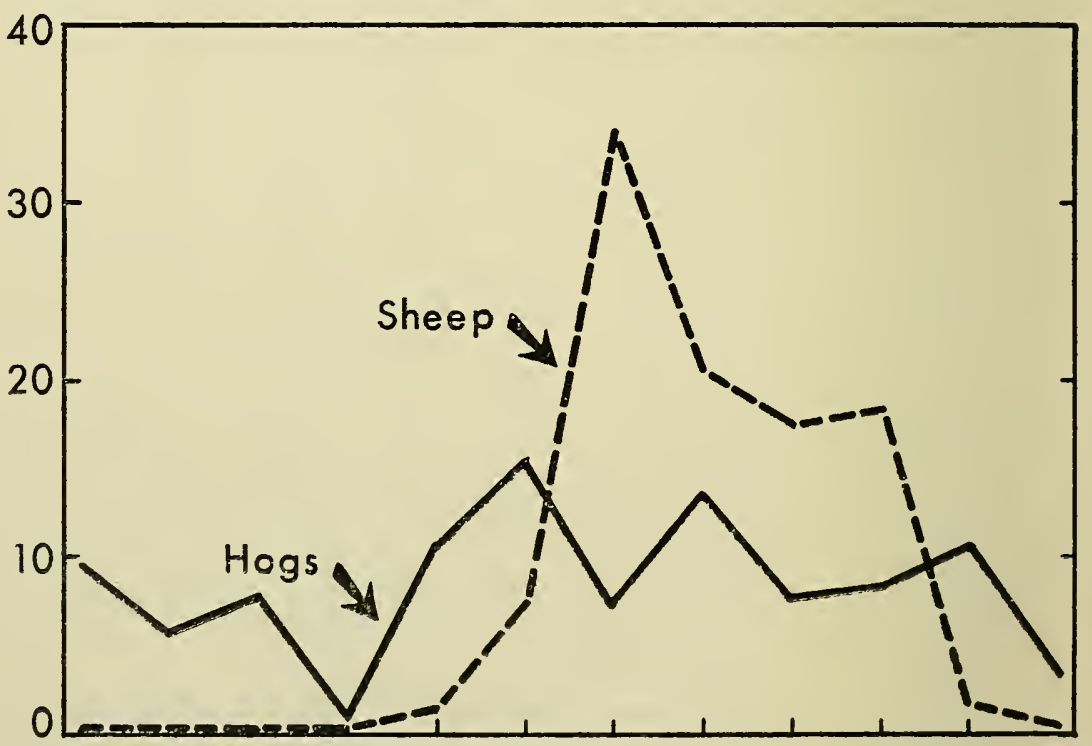

Jan Feb Mar Apr May June July Aug Sept Oct Nov Dec FIGURE 7. Percentage distribution of sejected classes of livestock sold each month by West Virginia farmers, 1950. 
16 per cent in June. Another 23 per cent were sold from January through March. April and December were the low months, accounting for 1 per cent and 3 per cent of the sales respectively. A high point in the marketing of pigs under three months of age was reached in May and June when one-third of the animals of this specified age were reported sold. Marketing of hogs three to five months of age reached a peak in August and in November, with these months accounting for threefourths of the sales of this age group. More than one-half of the hogs sold between the ages of five months to one year were reported sold in January, February, and March. Sixty per cent of those over one year old were sold in October, November, and December, and sales in August added another 27 per cent to this age group. (See Figure 7.)

\section{Seasonality in Marketing of Sheep}

Slaughter lambs showed the most seasonal use of the marketing agencies, with 90 per cent of the reported sales concentrated in July, August, September, and October. A peak was shown in July, with 34 per cent of the sales reported for that month. (See Figure 7.)

\section{MARKETING PRACTICES}

\section{Livestock Sold According to Size of Lots}

Fifty-four per cent of the cattle and calves were sold in lots of ten or more by 14 per cent of West Virginia farmers. Another 14 per cent of the farmers reported sales of 19 per cent of the cattle in lots of six to ten. Twenty-five per cent sold in lots of three to five, accounting for 16 per cent of the cattle sold. Only 7 per cent of the cattle were sold in lots of two by 21 per cent of the farmers, and 5 per cent of the cattle were sold in lots of one by 27 per cent of the farmers. (See Figure 8, and for information by market classes see Table 13.)

Of the hogs marketed by West Virginia farmers, 72 per cent were marketed by 33 per cent of the farmers in lots of more than ten; 18 per cent were marketed by 23 per cent of the farmers in lots of six to ten; 7 per cent were marketed in lots of three to five by 17 per cent of the farmers reporting. Only 2 per cent were sold in lots of two, and approximately the same percentage in lots of one. (See Figure 8, and for information by market classes see Table 14.)

Seventy per cent of the sheep and lambs were sold in lots of more than 20 by 28 per cent of West Virginia farmers. Another 11 per cent of the sheep and lambs were sold in lots of 16 to 20 by 16 per cent of the farmers. Ten per cent were sold in lots of 11 to 15 by 20 per cent of 


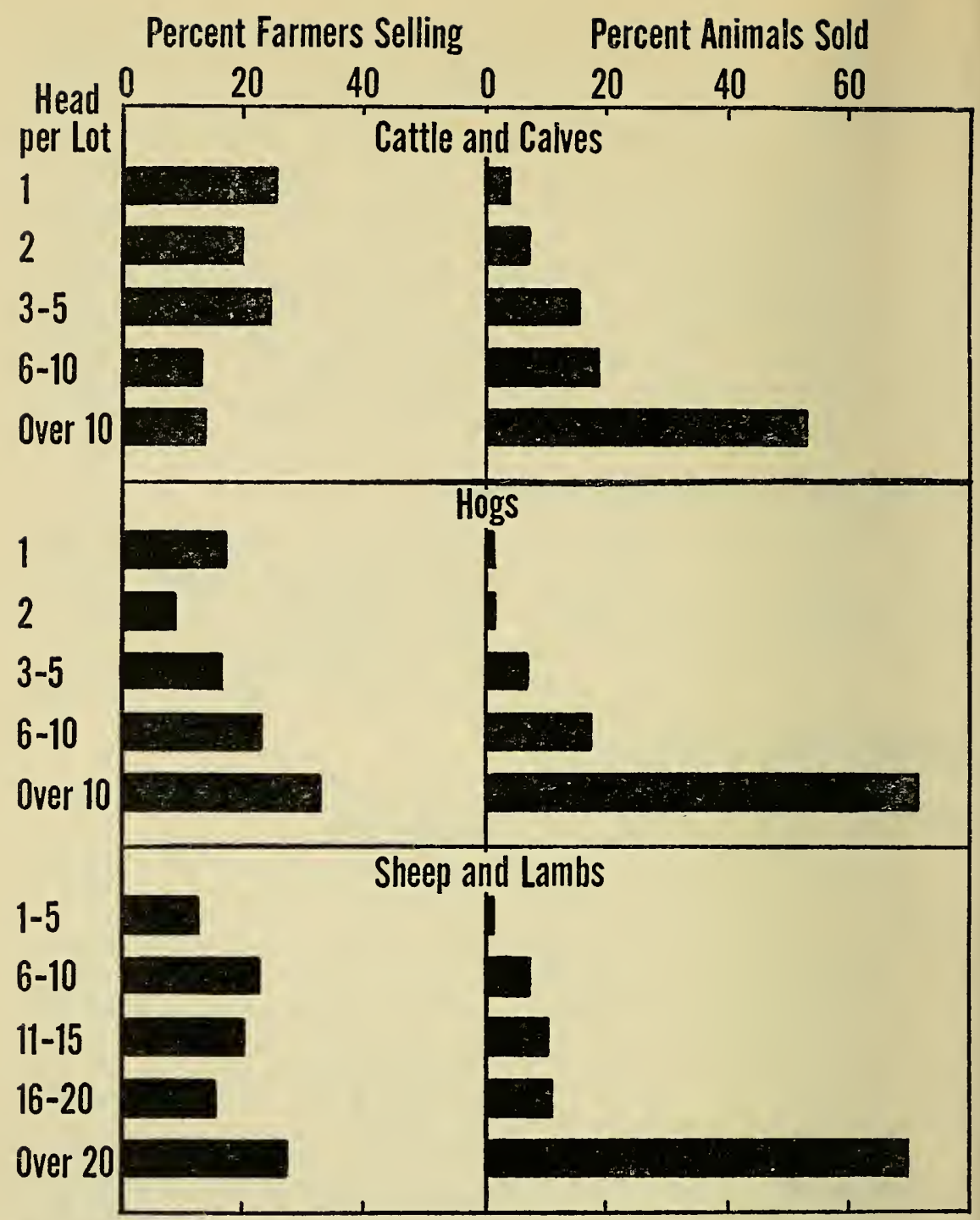

FIGURE 8. Distribution of West Virginia farmers selling livestock and distribution of livestock sold in varlous size lots, 1950.

the farmers. Seven per cent were sold in lots of six to ten by 23 per cent of the farmers, and 2 per cent in lots of one to five by 13 per cent of the farmers. (See Figure 8, and for information by market classes see Table 15.) 
Table 13. West Virginia Farmers Selling and Cattle Sold by Farmers Selling Specified Numbers Per Farmer in 1950, by Market Classes

\begin{tabular}{|c|c|c|c|}
\hline $\begin{array}{l}\text { MARKET } \\
\text { CLASS }\end{array}$ & $\begin{array}{c}\text { LOT SIZE } \\
\text { (No. SOLD } \\
\text { PER FARMER) }\end{array}$ & $\begin{array}{c}\text { Per chNT OF } \\
\text { FARMERS SELLING }\end{array}$ & $\begin{array}{l}\text { PER CENT OF ANIMALA } \\
\text { SOLD IN SPECIFIED } \\
\text { LOTB }\end{array}$ \\
\hline $\begin{array}{l}\text { Slaughter Cattle } \\
\text { (Other than real) }\end{array}$ & $\begin{array}{c}1 \\
2 \\
3-5 \\
6-10 \\
\text { over } 10\end{array}$ & $\begin{array}{l}40.8 \\
12.3 \\
20.8 \\
16.1 \\
10.0\end{array}$ & $\begin{array}{r}8.4 \\
5.0 \\
15.0 \\
26.1 \\
45.5\end{array}$ \\
\hline Veal Calves & $\begin{array}{c}1 \\
2 \\
3-5 \\
6-10 \\
\text { orer } 10\end{array}$ & $\begin{array}{r}37.0 \\
24.5 \\
25.0 \\
10.2 \\
3.3\end{array}$ & $\begin{array}{l}11.7 \\
15.6 \\
29.9 \\
26.8 \\
16.0\end{array}$ \\
\hline Stocker \& Foeder & $\begin{array}{c}1 \\
2 \\
3-5 \\
6-10 \\
\text { Over } 10\end{array}$ & $\begin{array}{l}27.0 \\
12.7 \\
19.0 \\
20.6 \\
20.7\end{array}$ & $\begin{array}{r}3.7 \\
3.5 \\
9.5 \\
20.5 \\
62.8\end{array}$ \\
\hline Dalry \& Breeding & $\begin{array}{c}1 \\
2 \\
3-5 \\
6-10 \\
\text { Over } 10\end{array}$ & \begin{tabular}{r|}
58.0 \\
16.0 \\
13.6 \\
6.2 \\
6.2
\end{tabular} & $\begin{array}{l}21.2 \\
11.7 \\
16.2 \\
16.7 \\
34.2\end{array}$ \\
\hline
\end{tabular}

\section{Relationship of Purchases to Sales}

In 1950 the number of all cattle and calves bought by West Virginia farmers was 34 per cent of the number they sold. The number of stocker and feeder cattle bought was 92 per cent of the number of that class sold, and the number of dairy and breeding cattle bought was 81 per cent of the number of that class sold.

The number of all hogs bought by West Virginia farmers was 56 per cent of the number they sold. However, the number of hogs bought for breeding was 175 per cent of the number reported sold for breeding, and the number bought for feeding was 95 per cent of the number sold for feeding.

The number of all sheep bought by West Virginia farmers was onethird of the number they sold. Yet, the number of sheep bought for breeding was 116 per cent of the number sold for that purpose, and the number bought for feeding was $\mathbf{8 3}$ per cent of the number sold for feeding. 
Table 14. West Virginia Farmers Selling and Hogs Sold by Farmers Selling Specified Numbers Per Farmer in 1950, by Market Classes

\begin{tabular}{|c|c|c|c|}
\hline $\begin{array}{l}\text { MARKET } \\
\text { ClaAsS }\end{array}$ & $\begin{array}{c}\text { LOT SIZE } \\
\text { (NO. SOLD } \\
\text { PER FARMER) }\end{array}$ & $\begin{array}{c}\text { PER CENT OF } \\
\text { FARMERS SELLING }\end{array}$ & $\begin{array}{c}\text { PER CENT OF ANIMALS } \\
\text { SOLd IN SPECIFIED } \\
\text { LOTS }\end{array}$ \\
\hline Slaughter Hogs & $\begin{array}{c}1 \\
2 \\
3-5 \\
6-10 \\
\text { Over } 10\end{array}$ & $\begin{array}{l}32.8 \\
12.0 \\
19.0 \\
10.3 \\
25.8\end{array}$ & $\begin{array}{r}3.5 \\
2.9 \\
10.0 \\
9.8 \\
73.8\end{array}$ \\
\hline Feeder Hogs & $\begin{array}{c}1 \\
2 \\
3-5 \\
6-10 \\
\text { Over } 10\end{array}$ & $\begin{array}{r}6.7 \\
11.7 \\
15.0 \\
33.3 \\
33.3\end{array}$ & $\begin{array}{r}.7 \\
2.5 \\
6.3 \\
26.6 \\
63.9\end{array}$ \\
\hline Breeding Hogs & $\begin{array}{c}1 \\
2 \\
3-5 \\
6-10 \\
\text { Over } 10\end{array}$ & $\begin{array}{r}80.0 \\
20.0 \\
- \\
- \\
-\end{array}$ & $\begin{array}{r}75.0 \\
25.0 \\
- \\
- \\
-\end{array}$ \\
\hline
\end{tabular}

Table 15. West Virginia Farmers Selling and Sheep and Lambs Sold by Farmers Selling Specified Numbers Per Farmer in 1950, by Market Classes

\begin{tabular}{|c|c|c|c|}
\hline $\begin{array}{l}\text { Market } \\
\text { Class }\end{array}$ & $\begin{array}{c}\text { LOT SIZE } \\
\text { (No. SOLD } \\
\text { PER FARMER) }\end{array}$ & $\begin{array}{c}\text { Per Cent of } \\
\text { FARMERS SELING }\end{array}$ & $\begin{array}{l}\text { PER CENT OF ANIMALS } \\
\text { SOLD IN SPECIFIED } \\
\text { LOTS }\end{array}$ \\
\hline Slaughter & $\begin{array}{c}1-5 \\
6-10 \\
11-15 \\
16-20 \\
\text { Over } 20\end{array}$ & \begin{tabular}{l|}
11.1 \\
27.0 \\
22.2 \\
15.9 \\
23.8
\end{tabular} & \begin{tabular}{r|}
1.9 \\
11.0 \\
14.2 \\
14.5 \\
58.4
\end{tabular} \\
\hline Feeder & $\begin{array}{c}1-5 \\
6-10 \\
11-15 \\
16-20 \\
\text { Over } 20\end{array}$ & $\begin{array}{r}25.0 \\
25.0 \\
-2 \\
25.0 \\
25.0\end{array}$ & $\begin{array}{r}5.6 \\
18.8 \\
35.7 \\
39.9\end{array}$ \\
\hline Breeding & $\begin{array}{c}1-5 \\
6-10 \\
11-15 \\
16-20 \\
\text { Over } 20\end{array}$ & $\begin{array}{r}53.8 \\
7.6 \\
23.1 \\
15.5\end{array}$ & $\begin{array}{r}2.9 \\
1.4 \\
8.6 \\
87.1\end{array}$ \\
\hline
\end{tabular}


The volume of livestock sold by West Virginia farmers exceeds the volume of purchases for all classes except breeding hogs and breeding sheep, indicating that breeding hogs and breeding sheep are moved into the State in larger numbers than are moved out, whereas the reverse is true for the other classes.

\section{Extent of Sales by the Head}

Cattre. Twenty-eight per cent of the cattle and calves sold were reported sold by the head. Of these animals about one-third were veals, about one-fourth more mature slaughter animals, about one-fourth breeding animals, and about one-fifth stockers and feeders.

Twenty-six per cent of the veal calves, 21 per cent of the more mature slaughter cattle, 23 per cent of the stocker and feeder, and 64 per cent of the breeding cattle sold were sold by the head.

Hogs. Fifty-seven per cent of hogs and pigs sold by West Virginia farmers were reported sold by the head. Of these, 13 per cent were for slaughtering, 86 per cent for feeding, and 1 per cent for breeding. Sixteen per cent of the slaughter hogs, 9I per cent of the feeder hogs, and 75 per cent of the breeding hogs sold were sold by the head.

SheEP. Thirty per cent of the sheep and lambs sold were reported sold by the head. Of these, 17 per cent were for slaughter, 1 per cent for feeding, and 82 per cent for breeding purposes. Seven per cent of the slaughter, 13 per cent of the feeder, and 92 per cent of the breeding sheep and lambs sold were sold by the head.

\section{Extent of Purchases by Live Weight}

Sixty-four per cent of the cattle and calves, 60 per cent of the hogs, and 100 per cent of the sheep bought by farmers, were reported bought on a live-rweight basis in 1950, and 36 per cent of the cattle, 40 per cent of the hogs, and none of the sheep were reported bought by the head.

\section{Extent of Sales at the Farm}

Catrle. Thirty per cent of the cattle and calves sold by West Virginia farmers were sold at the farm. Of these, 18 per cent were veal calves, 23 per cent more mature slaughter animals, 34 per cent stockers and feeders, and 25 per cent dairy and breeding animals. Fifteen per cent of the veal calves, 22 per cent of the more mature slaughter animals, 44 per cent of the stockers and feeders, and 69 per cent of the dairy and breeding animals sold were sold at the farm.

Hogs. Forty-five per cent of the hogs sold by West Virginia farmers were sold at the farm. Of these, 25 per cent were for slaughter, 74 per 
cent for feeding, and 1 per cent for breeding. Twenty-five per cent of the slaughter hogs, 63 per cent of the feeder hogs, and 63 per cent of the breeding hogs sold were sold at the farm.

SheEP. Sixteen per cent of the sheep and lambs sold by West Virginia farmers were sold at the farm. Of these, 12 per cent were for slaughter and 88 per cent for feeding and breeding. Three per cent of the slaughter sheep and lambs and about one-half of the feeding and breeding sheep and lambs were sold at the farm.

\section{Extent of Farmers' Attempt to Take Advantage of Seasonal Pricing}

Farmers were asked if they attempted to take advantage of seasonal price variations by giving attention to breeding dates, feeding programs, purchasing programs, and/or selling programs. Usually farmers who reported giving attention to any one of these practices indicated that they gave attention to all four practices. In most instances the practices were given attention by from one-fourth to one-third of the farmers affected. 

